\title{
The Larvæ of Certain British Crangonidæ.
}

\author{
By
}

Robert Gurney, B.A. (Oxon.).

IN the present paper I propose to give a brief account of the larvæ of two species of Crangonidæ-Cheraphilus trispinosus and Aggeon fasciatus. I shall not do more than describe the most characteristic features of the larva, as I hope soon to publish a more complete account of the development, with illustrations.*

The larvæ of Decapod Crustacea are a conspicuous feature of the plankton during the greater part of the year, and their identification being usually impossible without their complete metamorphosis being known, it seems to me to be worth while giving, not only a description of the above-mentioned larvæ, but also a diagnostic table for the distinction of all those Crangonid larvæ at present known.

In drawing up the table given I have depended largely on the paper of G. O. Sars, $†$ but I have been able to confirm his description of the larvæ of Crangon vulgaris, Cheraphilus nanus, and Pontophilus spinosus.

Of our commoner British species there remains only Aggeon sculptus to be investigated. I have found no larva in the tow-net collections during the present year not referable to one or other of the species named, and have only seen a single specimen of the adult. Its larva must therefore remain for the present unknown.

\section{The Larva of Cheraphilus trispinosus (Hailstone).}

An abundant supply of zoæas was obtained by keeping berried females in the laboratory tank till the hatching of the eggs. Unfortunately it was found impossible to keep the zoæas alive beyond the first moult, and in spite of the commonness of the adult, very few larvæ have been found in the tow-nets.

The first larva varies in length from 1.8 to $2.0 \mathrm{~mm}$., not including

* [This account has now appeared. See R. Gurney, "Metamorphoses of the Decapod Crustaceans AEgeon (Crangon) fasciatus (Risso) and AEgeon (Crangon) trispinosis (Hailstone)," Proceed. Zool. Soc., London, 1903, vol. ii. p. 24. E. J. A.]

† "Bidrag til Kundskaben om Decapodernes Forvandlinger, III. fam. Crangonidæ." Arch. f. Mathem. oy Naturvid., xiv. (1890).

NEW SERIES. - VOL. VI. NO. 4. 
the length of the rostrum; the average of twenty-five specimens being $1.9 \mathrm{~mm}$. The body is somewhat transparent and of a light greenish yellow colour, with a conspicuous, large chromatophore dorsally in the middle of the thorax. In general form it resembles closely the zoæa of Cheraphilus nanus, the thorax being not conspicuously broader than the first segments of the abdomen, which tapers gradually backwards.

The rostrum is short and pointed, but in later stages it is broad at its base and contracted sharply towards the apex, as is the case also in $C$. nanus. The ventral edge of the carapace is smooth though ending in front in a single short spinous prolongation. The abdominal segments are usually quite smooth, but the fifth segment may in some cases have a pair of short lateral spines. The tail plate is of the usual Crangonid type, with seven strong ciliated setæ on either side.

The inner flagellum of the first antenna is closely ciliated as in C. echinulatus. In $C$. nanus there are a few minute spines in addition to the cilia. The scale of the second antenna is narrow and elongated, with seven internal setæ and two setæ and a small spine apically. Externally there are two small setæ. The second antenna agrees closely with that of $C$. nanus, but differs from that of $C$. echinulatus in the narrowness of the scale.

The remaining appendages show no very characteristic features. The larva of C. trispinosus may be distinguished by its small size, and by the absence of teeth on the lower edge of the carapace and of spines on the third and fourth abdominal segments.

\section{The Larva of $\mathbb{E}$ geon fasciatus (Risso).}

The length of the larva when just hatched varies from 1.8 to $2.05 \mathrm{~mm}$., the average being $2.0 \mathrm{~mm}$. for twenty-four specimens. This measurement is exclusive of the rostrum, which is about $17 \mathrm{~mm}$. long at this stage. In general form of body the zoæa is not unlike that of C. trispinosus, but it is easily distinguishable. The thorax is not much broader than the first abdominal segment, and the carapace is prolonged forward into a long pointed rostrum. In later stages the rostrum is broad at the base and sharply contracted distally. The lower edge of the carapace is arched and without teeth, ending in front in a small blunt process.

The abdomen tapers but little, though the characteristically expanded epimera of the second segment make it appear considerably broader than the others. The third segment has a pair of backwardly directed dorsal spines; the fourth a pair of small knobs on the posterior dorsal edge, while the fifth segment has on either side a 
long, downwardly-curved blunt process, which in later stages has the form of a long hooked spine. The tail plate is of the usual form. The first antennæ are very long-about two-thirds of the length of the carapace. The inner flagellum is bluntly pointed and ciliated in the first stage. The scale of the second antenna is long and very narrow, with only six internal setæ, two setæ and a spine terminally, and two short external setæ. The palp of the first maxilla is two-jointed. The remaining appendages I will here leave undescribed.

The larva of AEgeon fasciatus can be at once distinguished by the length of the antennæ and the spines of the abdominal segments, the two lateral spines of the fifth segment with their terminal hook being very conspicuous, especially in the later stages.

\section{TABLE FOR THE DISCRIMINATION OF SPECIES HITHERTO DESCRIBED.}

1. ${ }^{*}$ Palp of first maxilla one-jointed . . . . 2 .

Palp of first maxilla two-jointed . . . . 3.

2. Third abdominal segment with a dorsal spine . Crangon vulgaris.

Third abdominal segment without a dorsal spine C. allmanni.

3. Abdomen more than twice as long as thorax . 4 .

Abdomen less than twice as long as thorax . 5 .

4. Telson deeply incised; posterior dorsal margin of abdominal segments smooth . .

Telson not deeply incised; posterior dorsal margin of abdominal segments with many small spines

5. Telson with more than sixteen spines

Pontophilus spinosus.

Telson with fourteen to sixteen spines . . 7 .

6. No dorsal spines on abdominal segments . . Sabinea septemcarinata.

7. Spines of fifth abdominal segment long, curved downwards at the end

Spines of fifth abdominal segment short and pointed, or absent . . . . . 8 .

8. Third abdominal segment with no dorsal spine Third abdominal segment with two dorsal spines

9. Inner flagellum of first antenna with cilia only Inner flagellum of the first antenna with cilia and small spines . . . . C. nanus.

* The mysis stage of Crangon differs from that of the other genera in having exopodites on the first four thoracic appendages only, instead of on the first five pairs.

+ In the first larva only. In later stages the larvæ must be distinguished by size, e.g. last stage : C. echinulatus, $4.80 \mathrm{~mm}$. C. nanus, $3 \cdot 30$ (Sars). 